\title{
NOÇÕES DE CORPORALIDADE E PESSOA ENTRE OS JODÏ*
}

Egleé López

Este trabalho é fundamentalmente etnográfico e pretende investigar como se articulam idéias e condutas nas noções de corpo e pessoa de alguns Jodï ( 900 pessoas), grupo indígena da Guayana venezuelana. ${ }^{1}$ Nesse sentido, procura circunscrever essas idéias e condutas no mesmo domínio analítico, a fim de explicar as dinâmicas socioecológicas ${ }^{2}$ dos grupos ameríndios (Viveiros de Castro 1992; Roosevelt 1994; Descola 1996a; Whitehead 2002). A articulação de idéias e práxis entre os Jodï é observada no conhecimento posto em ação diariamente, impresso em costumes, hábitos, cosmologias e mitologias; sua poética é a representação ou a atuação de eventos concatenados em tempos mitológicos e no devir cotidiano.

Os mitos Jodï tratam de como se fabrica e se recria a condição humana e como operam adequadamente os seres no cosmo. Igualmente, sustentam planos de manejo de recursos apropriados para subsistir e transformar o âmbito espaço-temporal concreto (Reichel-Dolmatoff 1971), recriam práticas histórico-sociológicas (de Civrieux 1980; Cayón 2002) e estão repletos de seres cujos nomes, formas e condutas se mesclam inextricavelmente com atributos humanos, botânicos, zoológicos e micológicos, em um contexto comum de intercomunicabilidade (Viveiros de Castro 1998).

Em termos práticos, os mitos Jodï constituem planos de uso territorial (incorporados como documento de manejo na solicitação de seu território ao Estado), são ecologicamente informados e estão imbuídos de um ethos emocional e moralmente único (Århem 1996a:200). Além disso, estão conectados a processos de fabricação, mutação, transformação ou metamorfose que recriam seres, pessoas e espaços (Viveiros de Castro 1987): acontecimentos aparentemente fixos no espaço e no tempo (a captura de uma anta, Tapirus terrestris; a coleta de palma, Attalea maripa etc.) relacionam-se exponencialmente à reprodução de eventos cosmológicos aos quais seguiram-se, por gerações, muitos outros similares. O mito concretiza-se e faz-se cotidiano 
ao passo que a ordem ancestral se recria no presente (Viveiros de Castro 1992:24; Århem 1996b:53), a vida doméstica articula-se constantemente aos fatos cosmológicos (Vilaça 2002:349) e a dicotomia entre o material e o imaginário dissolve-se na atividade diária espacializada no tempo. Exploram-se aqui três aspectos recorrentes da cosmologia e da vida Jodï: 1. a espacialidade do tempo primordial e do cotidiano; 2. o valor do som e seu contraponto com o silêncio; 3. a noção de alteridade que envolve diversas espécies.

Esta síntese não aspira à verdade. Tampouco se assumem exaustivos ou especializados comentários interpretativos oferecidos, embora se espere que descrevam com fidelidade as vozes e as práticas Jodï. Minha representação das idéias e das práticas desse grupo baseia-se nas diversas entrevistas sobre mitos conduzidas com 55 Jodï em múltiplas conversas e observações sobre os tópicos aqui expostos, nas variadas interações durante os nove anos de contato com eles e em minha própria cosmovisão e vivências. Exponho aqui fragmentos de algo muito mais complexo.

\section{Ecologia de subsistência}

Os Jodï assentam-se de maneira flexível e dispersa em ambientes ecológicos e sociais variados da Serra Maigualida, na Guayana venezuelana. Essa região montanhosa, de cerca de $7.000 \mathrm{~km}^{2}$ (altitude máxima de $2.400 \mathrm{~m}$ sobre o nível do mar), é coberta por matas altas e densas, com uma flora altamente diversa (López e Zent 2004). A maioria dos Jodï é monolíngüe, de idioma pouco conhecido (Dixon e Aikhenvald 1999:20) filiado à família Sáliva (Stanford Zent com. pess.). As 25 comunidades Jodï recenseadas têm sido expostas a graus diferentes de contato (com outras etnias, cientistas, missionários), gerando-se assim uma amplitude multipolar de trocas. Cerca de $40 \%$ dos Jodï vivem em comunidades pequenas (de 5 a 35 pessoas) e esparsas, e $60 \%$ da população nuclearam-se em duas comunidades de missão (católica e protestante) nas últimas duas décadas. Organizam-se em agrupamentos variáveis, altamente móveis e pouco estruturados (Storrie 1999:41). Mesmo nas missões, distribuem as casas em vizinhanças de parentes, semelhantes ao grupo originário pelo tamanho, pela cooperação econômica e pela estrutura (Storrie 2003 oferece uma análise sobre parentesco, a organização social e o incesto entre os Jodi). Observam uma divisão fluida ou nula do trabalho, um repertório mínimo de papéis sociais, a inexistência de qualquer segmentação social e uma notável ausência de nomes pessoais. Em compensação, são dotados de um formidável senso cerimonial. O pertencimento é criado mediante interação cotidiana, sustentada na circulação e na transmissão de 
bens, materiais, serviços e alimentos, informando a socialização e a identidade dos membros do grupo residencial (Storrie 1999:34; Rival 1998:354; Vilaça 2002:352; Londoño 2005:12).

A ecologia de subsistência Jodï compõe-se de caça, coleta de recursos silvestres, agricultura e pesca. Em média, 81\% do tempo para as atividades de subsistência são dedicados ao complexo caça-coleta e 19\%, a tarefas agrícolas. A obtenção de produtos silvestres ou cultivados associa-se à disponibilidade e à acessibilidade, mais que ao trabalho ou à propriedade, em um ambiente caracterizado pela dispersão, pela irregularidade sazonal e espacial dos recursos - concebidos e reunidos graças à interação favorável com seres sensíveis dadivosos que coabitam com os humanos, e não só como resultado da intencionalidade humana. Transcendendo a esfera material, a economia Jodï abraça um continuum de disposições, necessidades e intenções manifestas de seres humanos e não-humanos que modulam as estratégias de criação, troca, distribuição e circulação dos recursos.

\section{II. $\mathbf{O}$ sol}

Quando iyëka ja [homem inclemente, pícaro primordial] comeu a humanidade, jtinewa [o sol, homem muito grande] deteve seu caminho ao meio-dia até que ñamulie jaiñe [primeiro filho homem] subiu e o matou. ñamulie jaiñe gritou quando se fez a escuridão. Seus pais e seu irmão mais novo na terra não anunciaram a morte do sol. jtinewa renasceu pequenino do ijkwo jo [coração] do primeiro sol, mas cresceu rapidamente enquanto ñamulie jaiñe mostrava-lhe seu caminho. ñamulie jaiñe desceu à terra e se foi ao bosque com jtujtea [irmão mais novo, homem]. uli yewi [tigre grande, predador por excelência], ao vê-los, comeu ñamulie jaiñe. Por três dias, este voltou, ao crepúsculo, e pediu a seus pais e a seu irmão que lhe abrissem a porta. Sequer falaram com ele. Triste, à meia-noite do terceiro dia, ñamulie jaiñe despediu-se, dizendo-lhes: perderam a oportunidade de ser jluweoaï [eternamente jovens], morrerão e deverão seguir o caminho dos mortos, que hoje abrirei pela primeira vez. Partiu de onde sai o sol (mameka, rio acima, em jwaleu inëbo, montanha sagrada), até onde ele se oculta (chaka, rio abaixo). ${ }^{3}$

O mundo atual perceptível é um dos que foram fabricados no tempo primordial. Na última destruição, iyëka ja destruiu a humanidade depois de cortar as quatro árvores nïn alawini ${ }^{4}$ [Vitex spp.] que sustentam a terra nos quatro pontos fundamentais. O sol deteve seu caminho ao meio-dia. Nesse cenário caótico descrito em um complexo relato, escondem-se aspectos da ontogênese 
e da filogênese Jodï. O mito do sol nos vai guiando, de maneira tênue e em staccato, por aspectos significativos do ser humano. Parece concebido em três partes semânticas que, embora conectadas e sobrepostas, contribuem para o entendimento de três noções: pessoa, predação e eternidade. O mito expressa metaforicamente a natureza da distinção entre componentes corporais visíveis e elementos espirituais invisíveis da pessoa, juntamente com sua permeabilidade. Igualmente circunscreve três parâmetros das práticas de caça/predação que homologam o rito de iniciação xamanística e os eventos cotidianos de captura de presas. Finalmente, viabiliza as possibilidades de transformação e eternidade. Nos comentários que se seguem, as vozes do mito serão interligadas às práticas observadas entre os Jodï.

\section{Ila. A pessoa humana}

O mito do sol faz alusão a três componentes da pessoa Jodï, ijkwo ju [lit. coração, vida], ïnë ja dodo [lit. envoltório de carne animado, corpo palpável] e jnamodï [lit. espírito, ânimo], definidos em etapas da vida: nascimento, adolescência e morte. Como outros grupos das terras baixas sul-americanas (Butt Colson e Armellada 1983; Overing 2003), os Jodï não parecem ter um termo que traduza corpo no sentido ocidental, somente material: a totalidade do ser, ho [lit. ser humano], implica muito mais que o corpo material. Também não parecem conceber limites discretos entre seus componentes na pessoa individual e, muitas vezes, mesmo na pessoa social.

Nascimento. Coube a jkajo ja [nome genérico, homem sábio, inconstante, morfomutável, tornado imortal] repovoar a terra com homens. Conforme indicações de jcho ae [trovão, ser poderoso hipostático], ${ }^{5}$ talhou ñamulie $a \underline{u}^{\underline{6}}$ [a primeira mulher] do tronco de jtijtïmö jyeï [árvore sonora, Apeiba schomburgkii Szyszyl]. ${ }^{7}$ Pôs um ijkwo ju ${ }^{8}$ na parte mais interna do caule e, com isso, a humanidade brotou. O ijkwo ju é um componente complexo de muitos seres (sol, lua, animais, insetos, aracnídeos, homem, plantas etc.). Conforma o coração, no qual se assenta, e é a essência humana que traz sensibilidade e subjetividade. É o que primeiro existe no ser e, como o ïnë $j \underline{a}$, gera-se na concepção, provém de ambos os progenitores e cresce no ventre da mãe. O ïnë jạ é um equivalente aproximado do corpo e da pele, expressa a pessoa em matéria e define o habitus do ser propriamente dito, é substância potencialmente mutável que cinge o ijkwo ju.

Quando a primeira mulher nasce do tronco, jcho ae ensina a jkajo ja as tradições que regem atualmente a conduta Jodï com relação à couvade. ${ }^{9}$ Tais costumes relacionados à gravidez, ao parto e ao período pós-parto não são transferíveis aos animais (Vilaça 2002:355) e pautam a condição humana. Ao saber 
que um coração bate em seu ventre (engravidar), a mulher e seu par atualizam a paternidade compartilhada desde a gestação (Rival 1998): evitam o contato com certos animais (preguiças, jaguares, tamanduás), deixam de comer outros tantos (esquilos, aluatas, macacos-aranha) e algumas plantas (determinadas qualidades de banana e de inhame) e não caçam nem ocupam certos espaços (os picos da Maigualida, as montanhas baixas) para evitar malformações e destruição do feto e para protegê-lo de transformações corporais.

Tal como ao nascer a primeira mulher, o parto ocorre no interior da casa, na rede, em presença apenas do pai (só uma pessoa deve presenciar o nascimento). Quando a criança sai do ventre, deve olhar para onde o sol se oculta, denotando seu percurso. Conforme o sexo, um dos progenitores corta o cordão umbilical com Guadua sp. ou Arthrostylidium sp. Durante três dias, o grupo residencial mantém-se em silêncio. A placenta é envolvida em folhas de Monotagma laxum K. Schum. ou Calathea spp. No dia seguinte ao do parto, o pai participa diretamente da conformação do novo ser: embrenha-se na mata por três dias, enterra superficialmente a placenta entre as raízes de árvores leves, em solos suaves (se a árvore tem atributos opostos, a criança não crescerá), e pede a jcho ae que a leve. Como informa o mito, o pai pede durante três dias, em benefício do recém-nascido, jnamodï fortes, sãos e com boa disposição para a caça. Por isso, sonha e simula caçar na mata.

Os jnamodï são componentes intangíveis e invisíveis do ser humano, que insuflam razão, volição, conhecimento e sensibilidade e são a base da saúde. Tanto são fabricados quanto dados em três momentos liminares da pessoa: ao nascer, durante a adolescência e no curso de um rito de passagem e durante alguns treinamentos específicos. Ao nascer a criança, o pai sai por três dias em busca de folhas, cascas, raízes, flores e frutos de diversas plantas, água de cipó, cogumelos, aracnídeos e inseto ${ }^{10}{ }^{10}$ mastiga tudo para fazer uma massa a ser depositada em uma espécie de cesta de fibra e fabrica, absorvendo ao mesmo tempo, os jnamodï que jcho ae coloca ali. Na manhã do quarto dia, o pai volta e a mãe banha e esfrega o bebê com esse composto de substâncias que se infiltram, protegem e para sempre conectam, por suas essências, o recém-nascido com cada uma das espécies que conformam a massa. Com elas, penetram os jnamodï no ïnë jạ. Fazem-no forte, saudável e animado. A entrada de jnamodï, precedida por três dias de silêncio, é sucedida por um grito profundo. A consubstanciação consuma-se. Fustigam-se com certas folhas todos os integrantes da unidade doméstica para que seus membros sejam escarificados. Rompem-se, então, as restrições alimentares pré-parto e inicia-se a bênção da carne e do ser. Os pais do recém-nascido abençoam porções de uma série de plantas diferentes para cada um deles e se banham com elas. 
Os jnamodï são invisíveis, estão dentro, ao lado e em torno da pessoa (na mata, nas casas, na roça, nos rios) com a qual crescem, adotando a sua materialidade exata. No corpo, os jnamodï assentam no coração, que é, por isso, a parte que mais cuidados recebe dos Jodï (compare-se com a noção de espírito do coração ou a parte mais central do corpo material [Butt Colson e Armellada 1990:29]). jnamodï impregnam, absorvem, detêm ou desviam os mal-intencionados. Podem ser situacional e/ou contextualmente discretos ou não, ou seja, acompanham uma pessoa ou seu grupo, mas podem ser compartilhados por outras pessoas (gente, astros, plantas, animais, artrópodes, cogumelos). São altamente móveis e, portanto, é muito difícil determinar sua posição. O número de jnamodï varia, segundo o falante, entre um e quatro para cada pessoa, de acordo com a idade, a especialização ou o treinamento. A volição dos jnamodï é infundida contextualmente pelo coração e pelo corpo da pessoa. jnamodï são equivalentes em todas as pessoas e podem comunicar-se diretamente entre eles mediante transes ou sonhos (voam onde nasce o sol).

A doença ou o sonho expressam movimentos do jnamodï distanciando-se do corpo. Sonhar é uma arte que se apreende através do corpo. $\mathrm{O}$ treinamento para sonhar penetra-o mediante banhos iniciais (aos dois anos de idade) com folhas de jlojkodï, que ensinam aos jnamodï duas artes: caçar/explorar na mata [jcho balebï] e estar bem/curar [jtijai bae jtaye]. Enquanto o corpo é tangível e o jnamodï, intangível, o coração expressa ambas as características situacionalmente. Graças ao coração, vemos, sentimos, pressentimos, conhecemos, apreendemos, vivemos como seres sensíveis. Devido ao corpo, percebemos, pensamos e nos movemos, somos e estamos no espaço dos sentidos, individualizamo-nos, espacializamo-nos, transformamo-nos. Por meio de jnamodï sonhamos, pensamos, entendemos, compreendemos, somos quentes e não adoecemos. jnamodï escuta e comunica ao coração tudo o que vê em seus caminhos, nos sonhos, e insufla volição contextual no corpo. Logo que termina o sangramento pós-parto da mãe, celebra-se uma festa; os anos entre o nascimento e a adolescência só parecem incluir um rito antes da puberdade, quando se perfuram os ouvidos para facilitar a compreensão e a obediência da pessoa em formação.

Adolescência. Quando a primeira mulher chegou à adolescência e menstruou, jkajo jạ celebrou com ela as formas de ser Jodï (jejuns, caminhos, caça, frutos, silêncios, pinturas, banhos etc.). O casal primordial uniu-se e a vida insuflou-se neles como jkajo jadï ao apreender a forma Jodï e conceber dois filhos, ñamulie jaiñe e jtujtea, que garantiram a continuidade humana.

A consolidação da pessoa ocorre atualmente, como no tempo primordial, 
durante a adolescência, com a primeira menstruação, na mulher, e quando se observam os sinais corporais de puberdade, no homem. Celebra-se por meio de um ritual, como conta o mito. Envolve, como iniciados, indivíduos sozinhos ou um casal de cônjuges potenciais e inclui elementos espaciais, corporais, simbólicos e de conduta.

Os dois casais de iniciados pareciam extenuados, famintos e sem vontade visível. Várias noites em vigília, os jejuns e o consumo, pela primeira vez, da mistura de tabaco provocavam rictos cíclicos de consumo e vômito. Depois desse dia, poderiam descansar. A noite anterior tinha sido demasiado intensa. Sabíamos que a festa noturna era somente o auge do encerramento e que, embora chegasse já o sétimo dia, consistia na parte mais coletiva da celebração de um ritual complexo que se havia iniciado há pelo menos três meses. Cantos, flautas, passos contínuos de danças multiplicaram-se pela escuridão absoluta que guiou nossos passos. Ao chegarmos ao idö jnuwe [casa multifamiliar ovalada] precedidos por tochas, vimos círculos concêntricos de pessoas dançando, adornadas com saias, aventais e coroas de fibras de palma, além de múltiplos colares, braceletes e tornozeleiras fabricados com fragmentos de plantas, animais, cogumelos, insetos. Davam voltas na casa ao compasso de muitos sons atonais, de maneira global. A jangada de jtabali jamais tocaria a água, pois fora feita só para conter o iye jyu [bebida de batata fermentada] que regia a socialização depois do contundente som de cantos, músicas, danças... Alguns Jodï estavam muito impressionados com o ritual: era a primeira vez que o presenciavam, fosse porque vinham [...] de lugares onde se deixou de praticá-lo, porque não quiseram se submeter a ele, ou porque não tinham sido iniciados. Para outros, trazia a memória de sua própria iniciação e de suas particularidades diferenciais. Ficava claro, sim, que o evento era esplêndido para todos, não só para nós, os únicos não-Jodï que assistiam àquilo tudo.

O rito de passagem e iniciação desvela uma concatenação de três momentos (Viveiros de Castro 1987:36; Jara 1996:266): restrições e ensinamentos, marcador corporal e saída e hiperatividade e transbordamento. Espacialmente, isola-se o iniciado por período de sete dias a três meses (variável segundo o falante), durante o qual é encerrado sozinho ou com seu par em uma pequena casa feita para o ritual (com Attalea maripa Mart., Oenocarpus spp.), situada ao centro da casa cotidiana. O jovem dorme ali, em uma rede de Cecropia spp. nova. Um código de silêncio, nudez (sem adornos, colares ou pinturas), abstinência sexual, ausência de banhos ou limpeza e proibição alimentar de todo produto silvestre impõem-se ao iniciado (só se come milho, banana ou mandioca). Saídas solitárias permitem ao iniciado simular e dramatizar a vida de adulto. A cada dia, aprendem-se com os mais 
velhos as formas antigas: onde permanecer, como adornar o corpo, espaços e proteções, como sonhar, caçar, coletar, cozinhar, pescar, buscar ou chamar o ijkwo ju ou o jnamodï, fazer fogo etc.

Ao fim de muitos dias de isolamento, segundo o mito, o primeiro casal partiu em direção ao cume de uma montanha e, olhando para o sol, perfurou os narizes e tornou-se plenamente Jodï. Só ou com um adulto de seu próprio sexo, o iniciado sobe uma montanha. Durante o trajeto, protege a cabeça com um chapéu tecido (Socratea exorrhiza Mart.) para que ñëjto ja [arcoíris-pessoa predador] não saiba o que ele fará, e para evitar a penetração de qualquer substância danosa. Uma vez no topo, perfura o frontal superior do septo nasal ${ }^{11}$ com dardos de Oenocarpus bacaba Mart. O iniciado olha para o Leste, lembrando a rota do sol. Ao voltar da montanha e perto de casa, coloca o chapéu em um ninho de cupins e queima-o sob uma árvore dura. Alguns dias depois, põe no orifício nasal resultante da perfuração pequenos pedaços de madeira (preferivelmente Rinorea pubiflora, Licania apetala, Pseudolmedia spp.) que, sem serem visíveis ao exterior, ficam ali para sempre e são tratados com grande importância. A fase final do ritual consiste no retorno à sociedade (DaMatta 2000), na limpeza e na supressão das marcas da iniciação: as folhas que constituíram o pequeno recinto ocupado durante o isolamento e a rede de fibra são amarradas a árvores duras durante a manhã do último dia e são queimadas ao cair do sol, em uma ação acompanhada de gritos, conversas e golpes contra as árvores. O iniciado sai mata adentro de forma ruidosa, pratica libação com plantas determinadas, banha-se e enfeita exageradamente o corpo (adornos, colares, pintura) para beber, dançar e cantar à noite, em uma festa intensa. Na manhã seguinte, introduz-se o tabaco ao iniciado, que come todo tipo de alimento. Depois da festa, descansa-se uma semana e vai-se à floresta caçar. As primeiras presas são constantemente benzidas para que sempre haja animais à disposição.

O ritual implica uma conexão integral que relaciona o procedimento de iniciação à capacidade de viver propriamente como Jodï pois, com ele, apreende-se a realidade primordial. A partir desse rito, completa-se o treinamento de sonhar, iniciado ao nascer, e também se abre a vida de predação e caça do indivíduo em planos simbólicos, espirituais e de conduta.

O pequeno recinto imita uma casa em miniatura e atua como um espaço liminar. A reclusão dos iniciados assemelha-se ao intangível simbólico da metamorfose do corpo (Viveiros de Castro 1987:35). Após a perfuração nasal, o iniciado incorpora-se como humano, com toda a propriedade, à cotidianidade social e cosmológica Jodï. Pode-se fazer eterno. Ao morrer, um adulto cujo nariz não foi perfurado está condenado à extinção total, a ser comido por jlojkoi uli jạ [pessoa predadora enorme, hipóstase da lagartixa], já que só 
o nariz perfurado lança odores e sabores desagradáveis para o predador. As proibições alimentares revelam a consubstancialidade espiritual de plantas, cogumelos, aracnídeos, insetos e animais silvestres, pois só poucos cultivos podem ser consumidos. Como rito de passagem, esse momento liminar oculta significados mais profundos e propósitos mais intricados: alcançar com êxito o espaço eterno ao morrer, comunicar-se com os ancestrais e muitos outros seres sensíveis e adquirir o poder de curar. A perfuração nasal facilita a apreensão das formas de vida ancestral. Potencialmente, o iniciado se comunica com os Jodï primordiais e com aqueles que morreram, adquire seus modos e pode manipular uma margem mais ampla de corpos.

Um iniciado fabrica um corpo mais forte, mantém longe as doenças, é capaz de entender e conhecer mais, está protegido de predações e é hipersensível aos sons (os produzidos por crianças, filhos, predadores e outros). Depois do ritual, um Jodï adquire as habilidades xamanísticas que possibilitam e modelam a comunicação com espaços e seres. Fundamental, ademais, é conquistar o direito de comer tabaco, sem o que não se pode ter filhos (meses depois da reclusão pode-se ter sexo apropriado), reproduzir-se e fabricar-pedir jnamodï para seus filhos. O iniciado passa a dispor de mecanismos de comunicação e apreensão (sociais e cosmológicos) inacessíveis aos que não modificaram seu corpo, como sonhar bem. O rito estabelece uma continuidade de relações sólida entre objeto e sujeito, substância e eternidade, matéria e essência. Por meio da marcação corporal, modela-se física, simbólica e cosmologicamente a conformação do indivíduo como ser social, que baixa da montanha com uma nova consciência de complementaridade para com o seu grupo (DaMatta 2000:19). O ritual de iniciação concentra o significado de humanidade.

\section{Ilb. Predação-caça}

A predação factual e cósmica orienta implícita ou explicitamente muitas dinâmicas dos grupos das terras baixas sul-americanas (Butt Colson e Armellada 1983; Henley 1988; Silva Monterrey 1997; Whitehead 2002; Overing 2003). A segunda parte do mito aglutina uma seqüência de caça, persuasão-sedução, aniquilação com lança, humanização e metamorfose. Os primeiros homens conheciam apenas a luz, pois o sol se havia detido ao meio-dia, ao perder o caminho durante o último caos, e não havia noite. Já sábio, ñamulie jaiñe subiu ao céu com o corpo pintado, coberto de penas úmidas (de peru, mutum, arara) e couro de macacos, mas foram inúteis seus pedidos para que o sol o seguisse pelo caminho indicado. Viu-se obrigado, então, a matá-lo com uma lança de madeira. Gritou profundamente ao desferir-lhe o golpe. Fez-se a escuridão. Os pais e o irmão mais novo de ñamulie 
jaiñe viram formar-se a noite, mas não difundiram o feito de seu parente, que do céu lhes pediu para divulgarem a notícia da morte do sol. Experimentaram o medo, ao se sentirem rodeados na terra pelos que saíram no escuro (yewidï [lit. tigres poderosos e predadores], aweladï [predadores polimorfos altamente perigosos $\left.{ }^{12}\right]$ ). Depois de um longo tempo de escuridão, ñamulie jaiñe viu o sol renascer pequeno, como o filho de um pirilampo, tímido, procedente do corpúsculo central do coração do primeiro sol. ñamulie jaiñe mostrou-lhe o início, o meio e o fim de seu caminho, para que não o esquecesse. Restabeleceu-se o ciclo de dias e noites. O sol cresceu rapidamente, devido à comida que lhe deu (e dá) a gente em seu caminho. ñamulie jaiñe ensinou-o a fazer cestas, zarabatanas, esteiras, lanças, casas, redes, cantos, sonhos e ritos; desceu em seguida à terra, em forma de morcego, e sua mãe, a primeira mulher, banhou-o com o primeiro cogumelo que brotou de seu pé-madeira quando já era velha, convertendo-o em homem outra vez.

O imobilismo solar impossibilitava a transformação, o dínamo vital-social. Até agora, a metáfora sugere a transformação da madeira em vida-pessoa e, a partir dela, na humanidade completa, garantindo os ciclos (luz-escuridão) mediante a predação - relação que impulsiona a dinâmica entre os seres deste ciclo, indutora fundamental que insta à ação e à metamorfose. O sol morre e dá início a um ciclo vital. ñamulie jaiñe e jtujtea abrem as possibilidades de mudanças e transformações como humanos verdadeiros, completos. Sua tarefa primordial é fazer, à custa da predação, mover-se o sol - pessoa por excelência que, na cosmologia Jodï, interage com entes de todas as esferas espaciais (céu, terra, submundo e o rio que corre abaixo deste) e cuja rota está abarrotada de seres e espaços concretos. Durante a noite, o sol permanece em casa, junto a jcho malidekö, entidade primordial que, encarregada de definir quando o mundo acabará, comunica-lhe a cada amanhecer a sua decisão. O espaço solar garante essa forma de vida Jodï.

Talvez para celebrar o fim das restrições alimentares pré-parto e iniciar a caça, tanto Jani yewi quanto sua mulher tinham se lavado com cascas de árvore antes de se deitarem. Tomaram resinas e pintaram os rostos, os torsos e as extremidades. Lindos duetos iniciaram-se por volta das três da manhã. Jmejlo e sua mulher entoaram belos cantos do outro lado do riacho. Os sons que ela gerava pareciam cortar a noite e se reproduzir até o infinito. Jani yewi respondeu em uma entonação elevada, constante, alegre. O contraponto abraçou toda a comunidade de sete adultos nesta região isolada, escondida entre as árvores. Às cinco da manhã, saí para caçar com Jani yewi, sua mulher e seu bebê de três dias. No meio do caminho, os caçadores esfregaram o interior de seus narizes com folhas de árvores. A rota seguiu os frutos de jwaleko jyeï (Chrysophyllum argenteum), onde sete macacos comiam e brin- 
cavam. Ao sentirem nossa presença, silenciaram. A caça e a sedução consistiram em um minucioso trabalho em equipe. Uma hora mais tarde, o disparo certeiro de zarabatana alcançou dois macacos machos adultos (Cebus olivaceous).

A relação fundamental do perspectivismo Jodï manifesta-se nas práticas de predação e caça de maneira persistente e arquetípica, condensando, ademais, hábitos e representações xamanísticos (Viveiros de Castro 1998:14; Descola 1996b:90) em diferentes esferas de interação, cuja base é o corpo humano como elemento fabricado (Seeger et alii 1987). O xamanismo Jodï não é especializado. Considerando-se que a maioria dos homens, bem como muitas mulheres são caçadores, pode-se dizer que a caça articula a dinâmica social e aglutina a não-especialização da sabedoria xamanística. A forma de organização social Jodï tende a uma distribuição mais homogênea de poder, expressa no xamanismo não-especializado (similar ao caso dos Guajá, embora inclua mulheres, Cormier 2003) e na capacidade de mudança ou metamorfose de todos os caçadores (xamãs) que administram a relação entre humanos e não-humanos ao adotarem múltiplos pontos de vista.

Cada caçador atua como administrador de sua relação com as diversas espécies de animais, mas sua conduta afeta todos os caçadores de seu grupo. Cada um toma o lugar de intermediário humano com o mundo intangível da divindade. Suas ações modulam e assumem a responsabilidade do discurso humano ante os espíritos, articulando a comunicação mediada pelos jnamodï dos diversos interlocutores. As esferas de interação interconectadas variavelmente na caça Jodï são material tangível (espaço físico, instrumentação de caça, espécies associadas) e material intangível (conhecimento tecnoecológico, fenológico e etológico), acopladas a um corpo simbólico misto (mito, cantos, premonições, sonhos). Tais esferas correspondem tanto a uma expressão social concreta de conduta (caça com lança, zarabatana, em pares, em grupos etc.), quanto a uma manifestação corporal individual (pinturas, caça mágica etc.) - ambas inseridas em transformações que se intercomunicam: cada evento de caça reproduz a caça primordial em essência, mas não em aparência. A caça Jodï está articulada por meio de representações discursivas e pragmáticas: jcho aemodï, cosmologia e caça-mágica.

Os jcho aemodï [sing. jcho aemo, protetores dos seres, hipostáticos, vigorosos divinos-humanos polimorfos, grupos de pais e filhos, de intencionalidade variável, benignos ou predadores] equivalem aos Mestres dos animais freqüentemente citados na literatura (ver para os Desana, ReichelDolmatoff 1971; para Kapones e Pemones, Butt Colson e Armellada 1983, 1990; para os Eñepa, Henley 1988; para os Piaroa, Overing 1988, Mansutti 1997; para os Yanomami, Alès 1995; para os Makuna, Århem 1996a; para 
os Yek'wana, Silva Monterrey 1997; para os Patamuna, Whitehead 2002 e para os Guajá, Cormier 2003). São seres ideais, pessoas, sábios que têm seus pontos de vista, cuidam (com alimento, proteção, abrigo) dos indivíduos de seu gênero (Storrie 1999), reúnem todos os de seu tipo e regulam o fluxo de suas populações no espaço. jcho aemodï decidem quando, como e onde a comunicação com os de seu gênero (por meio da coleta, da caça, do toque e outros) torna-se possível. Desde o tempo primordial, cada ser, assim como todos os de seu tipo têm jcho aemodï e são tidos por eles. Os caçadores Jodï comunicam-se em diferentes graus com jcho aemodï, que facilitam a captura das presas, ou com as próprias presas. A caça Jodï é um ato xamânico e sua efetividade depende de experiências xamânicas.

A sedução entre caçador e presa inicia-se, tal como fez ñamulie jaiñe, com a complexa prática da pintura corporal [maluwe duwidekae]. O corpo do caçador, quando pintado com resinas (Protium spp., Himatanthus sp., Trattinnickia spp., Mabea sp. para homens e Aphelandra spp., Bixa sp., Psychotria spp., Garcinia sp. para mulheres), sementes, folhas e pedaços de certas espécies madeireiras suaves, atua como uma espécie de armadura que protege o eu contra seres malévolos ou perigosos, além de incidir positivamente na demanda de presas. Resinas e sementes mesclam-se com preparações de pó elaboradas com essências e extratos obtidos por defumação, queima e compressão da matéria (substâncias do coração de antas, macacos-aranha, gralhas e mutuns, partes ósseas e exoesqueletos queimados de vespas, escorpiões, tocandiras e outras formigas, lagartas, cartilagens de peixes, resinas). As pinturas corporais, negras ou de cores brilhantes, aplicam-se sem ordem a extremidades, peito, rosto, estabelecendo uma clara diferença perceptiva e factual com outros seres, em especial com aweladï. A pintura corporal (a) protege o eu de predações divinas, cósmicas e terrenas, assusta, afasta, confunde a percepção de criaturas danosas (ancestrais, animais, espíritos) (Cayón 2002); (b) atrai, agrada o Mestre do animal capturado, um predador potencial, e as próprias presas; (c) atua, ao mesmo tempo, como sensor sensível (localizado fisicamente nos corpos de homens, plantas, animais etc.) que conecta o caçador com o mundo primordial (López 2005).

No mito, o banho com o primeiro cogumelo é a metáfora que resume a prática da metamorfose mediante a penetração de substâncias (fabricação do jnamodï, caça-mágica, tabaco). A inserção de substâncias no corpo é precisamente o que inicia a mudança ao permeá-lo, dispondo-o à sucessão de transformações - nesse caso, homem-morcego-tigre-homem. O mesmo ocorre hoje quando o caçador celebra a caça-mágica por meio de abluções nasais, orais e corporais (libações, lavagens, inalações e banhos parciais ou totais) com porções de plantas, cogumelos, aracnídeos e insetos, a fim de 
ver, escutar, sentir mais agudamente o cheiro da presa e, ao mesmo tempo, purificar seu corpo (em caso de transgressões) e estabelecer laços efetivos e afetivos com as diferentes esferas orgânicas. Na tradição, envolvem-se partes de homens (nariz, boca, mãos), plantas (casca, flor, folha), cogumelos (himênio, parte superior, fluidos), animais (secreções biliares). Os indutores parecem deixar explícitos os laços de causa e efeito não-apreensíveis entre as esferas. Conectam os jnamodï do caçador com os aemodï do animal, seus eus espirituais complementares. Como no caso da pintura corporal, plantas, cogumelos, aracnídeos e insetos são veículos para alcançar a conectividade, pois atuam como indutores materiais, intelectuais e espirituais que confluem e coincidem para produzir uma caça bem-sucedida. Adscreve-se à prática uma transferência de propriedades. A caça-mágica expande a percepção do caçador, que acede à linguagem dos jcho aemodï para manter ou restabelecer a comunicação em caso de transgressão.

Sonhos e sons estão entre a parafernália de caça mencionada no mito. Sonhar é uma arte delicada e complexa, aprendida por certos homens e mulheres após treinamentos particulares (banhos, canções, histórias etc.). O sonho implica a comunicação preditiva, curativa e sedutora com múltiplos seres. O jnamodï do sonhador cria condições favoráveis à caça e pede aos Mestres um exemplar de seu gênero como presa. O talento de sonhar faz ver, conhecer e reconhecer (Crocker 1985; Butt Colson e Armellada 1983; Peluso 2004) a presa e a sua disponibilidade, e interfere positivamente com seu Mestre. Os caçadores cantam e tocam de maneira variada, conforme eles próprios (textos, flautas), o animal predado e a ocasião tempo-espacial. Canções e sons projetam uma caça bem-sucedida e agradam os Mestres.

O yule diye ou iyu, prática comum a muitos ameríndios (Århem 1996a), é uma espécie de conversação breve com o espaço onde morreu a presa, com sua carne e o resto de seu corpo, procedendo-se à purificação e à promessa de compartilhar as substâncias ou os alimentos a serem ingeridos. Traduzido como "bendición" [bênção] pelos Jodï hispanófonos, o iyu transforma o sujeito-animal em objeto-alimento por um ato xamanístico e foi concebido no tempo primordial pelo primeiro jkajo ja. ${ }^{13} \mathrm{~A}$ menos que a essência da presa seja parte do jnamodï fabricado pelo pai do comensal, pratica-se iyudï com os alimentos introduzidos pela primeira vez às crianças. As restrições alimentares em momentos liminares implicam a potencialidade dos Mestres dos animais para seqüestrarem (jovens, crianças, mulheres grávidas) ou predarem (adultos) as pessoas que consomem os de seu tipo, a fim de transformá-las em exemplares daquele gênero. O iyudï verbaliza a intenção de consumir, para que o indivíduo a ser ingerido reconheça que deve ir a seu lugar de origem e iniciar outro ciclo de vida individuada. Os Mestres ouvem 
o iyudï. A bênção da carne precede e sucede o consumo, dessubjetiviza o animal, desespiritualiza a presa capturada e garante o retorno de jnamodi do animal ao lugar de origem. A metáfora do mito solar humano impõe o regresso sempre pela mesma rota. O sol-pessoa controla o fluxo predador concentrado em seu espaço vital. Diversos animais-plantas-cogumelospessoas habitam esse espaço e vivem ciclicamente na terra, embora sempre permutando suas formas. A potencialidade mutável aparece no mito, no primeiro evento de caça terrena, quando os irmãos primordiais saem para caçar com uma luz tímida (o sol estava crescendo) e as silhuetas delatam, contextual e situacionalmente, a qualidade de presa-predador do ser.

\section{Ilc. Transformação e eternidade}

Morte. A última parte do mito informa sobre a condição mortal humana, sua relação com a predação, a transformação e a eternidade. Em um evento de caça e coleta de mel, o tigre abate o primeiro filho, que se despede, triste, de sua família, comunicando-lhe que abrirá o caminho a ser seguido pelos homens ao morrerem, depois de terem perdido a oportunidade de serem eternamente jovens, de trocarem de pele, como muitos répteis, e de rejuvenescerem para sempre. A mortalidade humana foi predestinada como conseqüência do medo. A morte é uma metamorfose resultante do silêncio, de um ato trivial de desobediência. Ao se deixar de anunciar a morte do sol abriu-se parcialmente a porta ao perecimento humano. O som do grito tem poderes significativos. A segunda oportunidade para abrigar a imortalidade foi também desperdiçada. Tanto o fato de a família negar abrir a porta ao filho mais velho por três noites consecutivas, quanto a incógnita a respeito do que ele fazia durante o dia indicam que ele era considerado perigoso - por ter revivido, agora metamorfoseado como seu predador, o tigre. Observa-se aqui um aspecto básico da predação Jodï: o temor da desaparição total é minimizado ante a idéia da transformação em um ser não-desejado, o do próprio predador. O tigre inverte a relação presa-predador. ñamulie jaiñe transforma-se em tigre e homem sucessivamente até hoje. A porta fechada é a possibilidade de vida humana real, mortal e cíclica. Abrir a porta e falar com o filho seria também possibilitar a predação. Eternidade, mas sem a definição humana. Uma transgressão final que desencadeia definitivamente a mortalidade e o caráter cíclico contemporâneo é o não-cumprimento do ritual de purificação de enterro e post-mortem do sol.

Ao morrer, o ser humano caminha até o lugar onde nasce o sol. Segundo a versão de criação a que pertenceu o Jodï morto, segue-se a rota do sol até os diferentes destinos finais (subsolo, sob as montanhas, céu etc.). Três componentes da pessoa — corpo, coração e jnamodï — sofrem transformações 
significativas e complexas, cuja viabilidade tem sua contraparte na terra, com a depuração ritual que os parentes executam. Seu não-cumprimento acarreta perigos de predação e contaminação substancial fatais. O imobilismo, a carência de vozes enlutadas no episódio da morte de ñamulie jaiñe, o silêncio de seus parentes e o fato de que não consumaram o ritual póstumo - tudo isso viabilizou sua metamorfose em um ser diferente, não-humano, e entorpeceu sua transformação espiritual. Atualmente, quando um Jodï morre, os parentes seguem condutas prescritas, análogas em estrutura ao rito de iniciação e que podem ser analisadas em três etapas.

1. Restrições e isolamento. O corpo de uma pessoa morta é lavado com substâncias vegetais e animais antes de ser enterrado ao longe. É vestido com uma tanga nova e sepultado em pequenas covas rochosas, na casa que o morto ocupou ou, mais freqüentemente, em matas baixas de espécies ecotonais. Abre-se uma cavidade em forma de casa onde se coloca o cadáver, envolto em uma esteira ou em rede de Cecropia spp, ao longo da qual cruzam-se estacas compridas e, sobre estas, folhas de Phenakospermun guyannense Endl. ex Miq., para que a terra não penetre e ofenda o corpo, que está vivo, em processo de transformação, e pode ver e sentir. Junto dele vão elementos úteis para o caminho (comida, bebida, curare, lança, zarabatana, pinturas, rede, colares etc.), bem como seus pertences, colocados ali a fim de que não seja necessário voltar para buscá-los. Durante o enterro, produzem-se sons contínua e copiosamente (pranto, grito, palavra). Tratase de uma advertência, em voz alta, para que o morto não regresse (Taylor 1993:662) sob qualquer forma de awela [transformações predadoras do corpo/ pele da pessoa morta]. Os vivos afastam-se para evitar ataques (doenças, seqüestros de crianças, jnamodï) ou sustos provocados por awela, que assume diversas formas, de acordo com sua decisão no instante imediato da morte. A volição do corpo no processo de metamorfose é crucial, pois a forma adotada definirá tanto sua percepção dos entes e do ambiente à sua volta quanto seu caráter predador (semelhante a grandes macacos-aranha, veados negros, ratos escuros). Ficar em casas onde morreu alguém é um convite à predação por awela, sempre à espreita, prestes a ferir e a matar. A proteção durante os ritos funerários é obtida por meio da ingestão de certos cogumelos e do recurso ao adorno pessoal (pintura corporal com resinas arbóreas e substâncias extraídas de aracnídeos e insetos, uso de colares, enfeites, ossos, penas etc.): mediante o ardil de fazer-se parecer outro ser, assusta-se awela. A máxima proteção advém do ato de untar com determinado cogumelo [awela yákilo] e água o pedaço de madeira a ser inserido pela primeira vez no orifício nasal. 
2. Marcador e depuração corporal. Depois do enterro, a casa do grupo é queimada e constrói-se uma nova, a uma hora de distância a pé. Durante cerca de três meses, os parentes e especialmente os que tocaram o cadáver devem lavar suas mãos, banhar-se, vomitar e fazer abluções. Os Mestres dos insetos recebem, purificam e curam-lhes o sangue. Por isso, enquanto se distanciam, após o enterro e durante o rito funerário, os parentes expõem-se persistentemente a picadas de diversas formigas, sobretudo nas mãos que, em seguida, devem ser lavadas com substâncias vegetais determinadas (diferentes conforme o sexo) sobre os formigueiros. Também sobre eles derramam o sangue que escorre de suas bocas e de seus corpos, escarificados com folhas específicas. Evitam comer produtos silvestres e praticam iyudi com os alimentos que podem ser ingeridos (milho, banana ou mandioca), em uma dieta muito estrita. Mantêm silêncio durante esse tempo e se abstêm de relações sexuais. Aqueles que enterraram o morto não tocam nas crianças até o primeiro banho quente que, com algumas plantas específicas, os parentes tomam depois de um mês.

3. Atividade e transbordamento. Ao terceiro mês de luto, começam a comer gradualmente diversas substâncias (pequenos peixes assados, caranguejos, frutos da mata etc.), até que, ao sexto mês, ingerem carne e celebram uma festa (realizada também pelos Eñepa, Henley 1988:282) na nova casa, quando choram com intensidade para que o defunto escute, perceba que está definitivamente morto e não regresse aos espaços cotidianos de seu grupo. Ao fim do ritual, não há referentes que remetam à memória do morto (Taylor 1993:655).

Deixar de praticar a purificação póstuma é incitar o morto/awela a produzir calamidades ou doenças, em um estado de ilejtaibujtebï [desânimo, inapetência, mal-estar] que pode ser crônico e fatal (Århem 1996a). Se os ritos funerários são cumpridos, viabilizam-se as transformações dos jnamodi e do coração. Um dia depois do enterro, uma pessoa diminuta sai do coração do defunto e com os jnamodï individualiza-se e renasce do coração, como o sol, retornando eternamente. Renasce após deixar a dor. O coração, ao morrer, induz ao sonho e à transformação. Chora, então, o morto diminuto por saber-se só. Os yowalibuka jạdï [espíritos mortos tornados eternos, que vivem onde nasce o sol, têm suas casas rodeadas de tabaco e indicam o caminho solar aos que morrem] baixam, alimentam-no e consolam-no. yowalibuka $a u$ [mulher] toma a criança, leva-a até o rio no fim do mundo, ajuda-a a cruzar as águas e despede-se dela. A caminhada é tão longa que a criança se torna adulto ao fim da rota do sol que cada ser humano percorre sozinho ao morrer. Na metade do caminho (onde o sol tinha se detido), está o maior 
predador, jlojkoi uli jạ. Se o morto não tiver a perfuração nasal e o pedaço de madeira inserido no orifício, será frito, em uma grande frigideira, no seu próprio sangue. Em seguida, será devorado e estará extinto para sempre. O sangue dos que não perfuraram o nariz é doce; o sangue daqueles que cumpriram o ritual é ácido e malcheiroso. jlojkoi uli ja enfurece-se ao ver o nariz perfurado e atira o coração sobre palmas espinhosas. Ao ouvir seus gemidos, yowalibuka au ajuda-o a seguir seu caminho com jnamodï até a casa do sol, onde espíritos bons o recepcionam e lhe dão comida, faca e facão. Nesse lugar, yowalibuka ja transforma-se, deixa de ser homem real e se faz espírito, converte-se em jkajo jạ, como os seres divinos, e começa a viver sem dor. Ali a pessoa esquece toda a sua individualidade terrena e é recebida com uma festa de boas-vindas.

Associado à penetração de substâncias e à corporalidade, o ritual de iniciação é significativo no que se refere à predação e à morte: só sobrevivem eternamente os que portam em seu nariz perfurado pedaços de madeira e, portanto, têm o hábito de consumir tabaco. Observar o ritual é defender-se dos predadores e garantir a vida. O tabaco protege de duas classes de predadores: aweladï e os que atacam por transgressão (pessoas-colibri, lagartixa ou sapo, hipostáticas). Ambos os tipos comem o coração e o jnamodï, e são temidos especialmente em espaços liminares marcados pela potencialidade da transformação: ao nascer, durante a iniciação e ao morrer. As pessoas-lagartixa, sapo e colibri não são comestíveis e, como outros seres da cosmologia Jodï (gambá, preguiça, urubu), assemelham-se a espíritos muito poderosos. Os corações abatidos por jlojkoi uli ja extinguem-se para sempre no zênite, no lugar do imobilismo do sol.

A imortalidade de animais e plantas é subordinada à conduta humana. Animais e plantas, diferente de homens verdadeiros, não se transformam em awela. Os animais têm jnamodï e coração, mas só alguns insetos possuem ambos. Certos vegetais têm jnamodï, todos têm Mestre protetor e uma forma de coração assentada no interior da casca mais interna do caule, jkwatakä (onde se colocou o coração da primeira mulher). Muitas plantas são pessoas que potencialmente abatem homens que delas abusem. Algumas são casas de pessoas e mantêm relações de afinidade com os Jodï. Ao morrerem como presas ou serem colhidas na mata, seus corpos penetram e transformam, exponencial e explosivamente, aqueles que as consomem.

\section{O caminho do sol: jornada transicional}

Esta seção investiga a espacialidade, o poder do som e a alteridade. 
O espaço Jodï é marcado por uma intangível segmentação ou compartimentação do ambiente que o rodeia, com implicações reais das condutas ecológicas. O espaço mítico do tempo primordial é a floresta alta, coabitada por um sem-número de seres sensíveis que dela se apropriam sem a possuírem. A relação espacial do caçador, do coletor, do agricultor está imersa em tal segmentação. Quando um Jodï se dirige à mata para realizar uma tarefa mundana, a espacialização do tempo contém imagens do agora e da época primordial: adolescentes Jodï pescando, um casal caçando, uma família colhendo palmas, mulheres procurando caranguejos etc. Eles sabem que em volta da corredeira, da mata ou do rio existem peixes, animais e plantas, além de inúmeros seres intangíveis que determinam sua conduta ecológica. Ocorre o mesmo com a disposição geográfica das comunidades e das casas de Leste a Oeste, e até das portas diminutas usadas exclusivamente por mulheres menstruadas para evitarem transmitir doenças aos caçadores. Com base na setorização do espaço Jodï, dá-se corporalidade a muitas condutas e, a partir da diversidade de corpos em movimento, geram-se práticas específicas.

Nas esferas orgânicas do imaginário ecológico Jodï, sucede-se a transidentificação ou o intercâmbio das qualidades e das essências espirituais e materiais dos seres. Cada vez que um predador humano age, as conversões primordiais (homem-animal-cogumelo-planta-esfera celeste) recriam-se e operam novamente, garantindo a reciclagem constante e permanente de presas e transformações. Mas sobretudo os encontros com animais estão permeados de transmutações dicotômicas que envolvem o ser real percebido e o percebido sendo real (López 2005). Macacos, tigres, mariposas, rãs, tucanos, formigas, árvores etc. podem ser algo ou alguém diferente do que parecem. Apesar disso, ou por isso, a efetividade da subsistência depende e pende do conhecimento da maneira como se expressam os aspectos materiais das espécies que informam a ordem cósmica e a sua remissão ao tempo primordial. O comportamento único da espécie é diferencial e converte-se em fator importante para as condutas ecológicas e a série de inter-relações e interdependências.

Os múltiplos lugares sagrados que marcam o espaço físico como assentamentos para as casas-receptáculos de seres são os espaços de predação por excelência. Sagrado é o local onde se deve ter cautela devido à sua potencialidade predadora, onde não se emitem sons nem se pronunciam nomes significativos. Os Mestres protetores ocupam áreas particulares em setores montanhosos, rios, depressões, rochas, no céu, no subsolo ou em algumas árvores, fontes de águas estanques ou correntes. Os Mestres dos animais estão ligados a árvores e a cogumelos específicos, em complexas redes de relações marcadas lingüisticamente ou como categorias cobertas, ${ }^{14}$ e decidem quantos deles coexistem em um tempo e em um espaço particular. 
As populações de plantas, animais e cogumelos são constantes. Sua incorporação ao espaço geográfico Jodï renova-se ciclicamente e faz contraponto entre seus espaços eternos ou suas casas e os espaços terrenos espécie-específicos. Os Mestres protetores espacializam em eterno retorno a demanda de presas (deixam sair um exemplar de seu tipo pela rota do caçador) e remetem, com acuidade, ao tempo contemporâneo-primordial pois, quando uma presa é capturada, seus jnamodï regressam sempre à mesma montanha primordial onde reside seu Mestre e, em fluxos eternos constantes, dispersam-se pelo mesmo habitat, uma vez que se transformam em corpos novamente. Os predadores têm recintos determinados: mana jádï, [pessoas morfomutáveis malcheirosas que provocam enjôos] vivem sob algumas corredeiras; os yewidï [hipóstase de tigres-pessoas], em lagoas subterrâneas; e os yulue ilebo, na montanha da zarabatana.

Além da percepção visual, o contraponto entre palavra e silêncio é onipresente na cosmologia Jodï como modulador de transformações e estratégia xamânica. Pensamento, conduta e palavra são indissociáveis, como em outras tradições ameríndias (Mansutti 2002:33). O silêncio marca estados liminares (prévios à entrada do jnamodï no corpo do recém-nascido ou no corpo do sol quando o matam com a lança; durante o período de reclusão no ritual de iniciação; antes de se consumir pela primeira vez qualquer alimento etc.), mas também é considerado transgressão (quando o primeiro casal não gritou-falou ao morrer o sol, ou quando novamente se calou por três dias depois de ñamulie jaiñe ser capturado pelo tigre e transformar-se em tigre-pessoa) e causa de mortalidade. O poder do som-palavra é uma metáfora de transformação e criação (Mansutti 2002) e tem implicações na conduta cotidiana, como se constata na necessidade de não se mencionarem os nomes de lugares sagrados-espaços potenciais de predação (porque a sua simples menção poderia estimular a percepção e a materialização do predador que os ocupa); no ato de benzer os alimentos para evitar qualquer mal associado às substâncias que se consomem e penetram a pessoa; ou na verbalização, associada à pintura corporal (feita com plantas, animais, insetos, aracnídeos e cogumelos), do desejo de que o interlocutor adoeça. A espacialização do tempo e o poder do som estendem-se pelo território Jodï com referentes concretos. Observa-se uma extensa proibição de enunciar nomes de múltiplos lugares sagrados, onde se sucederam transformações em épocas primordiais e para cuja aproximação são requeridas pautas de conduta estritas, normas rígidas de silêncio e respeito (por terem sobrevivido a todas as destruições, os nomes de picos da Maigualida jamais devem ser mencionados; ademais, nomes de corredeiras e lagoas incitam à predação, e assim por diante). 
O mito - e sua reprodução habitual na rotina Jodï — sustenta a afirmação de que o corpo totaliza uma visão particular do cosmos (Seeger et alii 1987:22-23), especialmente mediante sua fabricação intencional e periódica (Viveiros de Castro 1987:32). Reproduz-se a essência solar (humana), penetrada por alimentos para estimularem a continuidade e a transformação: a ciclicidade do sol faz com que a humanidade baixe do céu e povoe a terra abundantemente.

A realidade ou a existência do outro entre os Jodï não se explica com base em oposições (essenciais, substanciais, posicionais etc.). Embora não sejam humanos completos, os homens sem jnamodï podem adquiri-lo ao se submeterem aos rituais apropriados. Essa percepção congrega o ethos Jodï sobre o outro. A vontade de ser e estar individual mostra-se complexa (faz-se assimétrica), em virtude da possibilidade de tornar difusos os limites do eu discreto mediante a consubstanciação (Descola 1996b:138) presente hoje em quase qualquer atividade Jodï e constituinte da noção de alteridade. A esta associa-se diretamente a relação situacionalmente mutável entre seres (presa/predador) ontologicamente análogos (Århem 1996a:193).

Um traço distintivo na cosmovisão Jodï advém da idéia de que a humanidade não se desmembra em animais, plantas, cogumelos, esferas celestes etc. por castigo ou transgressões, como em outras cosmologias ameríndias (de Civrieux 1980), mas por intenção individual, a qual leva diversos homens a adotarem formas, hábitos e habitats distintos, conformando-se assim a esfera perceptual espaço-temporal do mundo em vigília contemporânea. A divindade-humanidade de vários dos mitos de criação-transformação de homens em diversos organismos ${ }^{15}$ expressa-se nas relações de parentesco que muitos Jodï mantêm hoje com animais e plantas, e no profuso e constante uso de substâncias ${ }^{16}$ vegetais, zoológicas e micológicas que penetram o corpo humano e o transformam ciclicamente.

A discricionariedade aparente dos três componentes de pessoa que comentamos extensamente (corpo, jnamodï e coração) aparece permeada e modificada por múltiplas substâncias, consideradas intencionais e dotadas de agência - entre as quais estão o sangue e o tabaco, elementos paradigmáticos. Nos períodos liminares, o sangue ${ }^{17}$ determina múltiplas condutas relacionadas à interação de substâncias orgânicas (a lógica das restrições alimentares remete à periculosidade do consumo de animais que contêm sangue em demasia); aos espaços (mulheres menstruadas devem usar diferentes portas e caminhos); à eternidade (jlojkoi uli ja prova o sangue para decidir o destino da pessoa); ao pertencimento parental (o sangue vem do pai e da mãe em proporções iguais); à saúde (a escarificação do corpo remove o mal-estar causado por contaminações, transgressões, acumulação etc.); aos 
movimentos (fluxos de sangue entrando/saindo do corpo delimitam diferentes comportamentos) e assim por diante. O tabaco está ligado à concepção de eternidade, força e permanência. É uma das substâncias que penetram a pessoa e informam sua conduta (Londoño 2005) - ele cura, anima o enfermo debilitado mediante sopros que transportam a vida. Os Jodï sempre levam com eles o tabaco, em especial quando vão à mata caçar.

A entrada dessas substâncias no corpo facilita o acesso, com igual potência espiritual, à esfera dos Mestres protetores. Há muitos outros exemplos na cosmologia Jodï que insistem na volição humana em contraponto com eventos discretos de locus divino que transcendem o tempo primordial e se fazem contemporâneos, sintetizando espaços sincrônicos como diacrônicos. Para os Jodï, nesse sentido - e diferente do que ocorre com alguns outros grupos ameríndios - determinadas plantas e algumas espécies de cogumelos apreendem espiritualidades tão importantes quanto as de muitos animais, equiparando-se às da Amazônia ocidental (Viveiros de Castro 2003:199).

\section{Conclusões}

As noções de corporalidade e de pessoa Jodï estão intimamente relacionadas. Ambas atuam como dobradiças, articulando idéias e práticas. São construtos que, com base em discursos e silêncios (mitológicos e cotidianos), convertem-se a partir de práticas e costumes e da sinergia de diversas essências e substâncias (plantas, animais, artrópodes, cogumelos etc.). Embora os espaços silenciosos e os verbalizados sejam esferas particulares, a transgressão do som - ou o silêncio - é central na definição da humanidade e serve de combustível a diversas transformações. A audição é inclusiva nas metamorfoses, na gradação e na continuidade da vida. As condutas Jodï, bem como seus corpos fabricados e dados estão inerentemente imersos, desde sua gênese, no ambiente socioecológico circundante. Informam-se com as substâncias e as essências que são. Nesse sentido, a noção de alteridade entre os Jodï conjuga-se à penetração de substâncias e essências, articulando mamíferos, insetos, aracnídeos, plantas, cogumelos e outros, ou seja, envolvendo seres de materialidades muito diversas, a ponto de tornar difícil a idéia de discricionariedade dos entes e de sustentar a permeabilidade e o pertencimento. Igualmente, o espaço geofísico Jodï parece encerrar uma corporeidade material do tempo. Eventos míticos primordiais trasladam-se ao espaço liminar do ritual e ao espaço cotidiano do dia-a-dia. O espaço e o tempo também não parecem ser concebidos como dimensões discretas. 
Os Jodï espacializam o tempo diariamente. O espaço onde se sucedem os eventos funde o ambiente físico circundante e a ordem cultural (Ingold 2000:189), as noções do dado e do modificado, que usualmente ocupam oposições teóricas. O ambiente dos eventos mitológicos e cotidianos pode ser observado na rotina Jodï (eventos de coleta, pesca, caça etc.). Um exemplo é a rota do sol, corporeidade material da espacialização do tempo, com implicações de conduta no presente. Além de marcar ciclos temporais de continuidade, a rota solar Jodï esconde uma genuína possibilidade de metamorfose e articula a espacialização das origens e da escatologia humanas, operando como metáfora dos estados liminares e da definição do ser. O caminho do sol é um tema recorrente nas mitologias ameríndias. É parte, por exemplo, do treinamento xamanístico Tukano (Cayón 2002:89-90,177); é usada pelos xamãs Araweté ao ascenderem ao céu e quando deuses e almas descem para participar de cerimônias (Viveiros de Castro 1992:61); entre os Yabarana, o sol se detém no zênite, impedindo mudanças (Wilbert 1958:60); o espaço caótico dos Desana carece de luz (Reichel-Dolmatoff 1971:25); os Bororo dividem a aldeia por meio de uma linha leste-oeste, paralela ao trajeto do sol, definindo e determinando, assim, relações sociais (Crocker 1985:30); a energia vital cósmica entre os Pemón e os Akawaio provém do lugar do sol (Butt Colson e Armellada 1990:15); os heróis cosmológicos Patamuna eram irmãos e filhos do sol e instauraram as condições da sociedade humana (Whitehead 2002).

Em síntese, sem esgotá-los, podemos dizer que certos aspectos das vozes ecocosmológicas Jodï ocupam espaços semânticos análogos a alguns postulados observados para o contexto ameríndio:

1. Indiferenciação primordial. O meio biótico e boa parte do meio abiótico no universo Jodï parecem, quase invariavelmente, gerar-se na condição humana (Butt Colson e Armellada 1983:1233, 1990:44; Descola 1996b:132; Viveiros de Castro 1998:11). O devir das transformações registradas na cosmologia remete ao tempo unificado primordial, mas jamais como início ou criação sem elementos prévios e, sim, como modificação de algo (Viveiros de Castro 1998:12).

2. Corpo e Sociedade. A apreensão (corporal-material e conceitual-imaterial) do corpo Jodï não só dimensiona e cria a pessoa (ser-sujeito orgânico), mas também parece resolver em síntese dinâmica as carências dos paradigmas materialistas e idealistas, opostos entre si (Ingold 2000:5). A pessoa e a corporalidade Jodï são fabricadas em práxis concretas; a fisiologia é dependente da cultura (Seeger et alii 1987:15; Viveiros de Castro 1987:32; Alès 1998:282). O corpo informa práticas de subsistência e rituais que moldam subjetividades e enfatizam a condição social do indivíduo Jodï (DaMatta 2000). O sujeito não está circunscrito ao homem como espécie, mas a diversos seres e objetos relacionais e situacionais aos quais se 
atribuem intencionalidade, racionalidade, sensibilidade e autonomia (Viveiros de Castro 1992; Taylor 1993:659; Århem 1996b:6).

3. Interpenetrabilidade e Etnocentrismo. A cotidianidade Jodï é marcada pela certeza da potencialidade real do caos, evitada pela existência da forma biocultural Jodï. Os Jodï foram materializados no universo para manterem e reproduzirem a interconexão, a relacionalidade e a interpenetrabilidade total das esferas, axiomaticamente por meio da caça (Århem 1996b:201; Viveiros de Castro 1992, 1998). A alteridade — ou seja, as outras formas de existência — está subordinada aos humanos verdadeiros (Descola 1996b:132): os que conjugam a corporalidade (substância tangível) e a refletividade (essencialidade intangível). Trata-se de declaração freqüente em outros grupos ameríndios (Wilbert 1992; Viveiros de Castro 1998).

4. Habitus e Umwelt. O âmbito espaço-temporal dos eventos, bem como a inclinação (percepção sensorial limitada e parcial do ambiente que o ser individuado experimenta), a intencionalidade e o comportamento (Viveiros de Castro 1998:41) das espécies envolvidas recriam séries de redes de apreensão traduzidas em objetos de experiência sígnica (Hornborg 1996:52; Deely 2001:129).

5. Dwelling e Predação. O cenário onde se sucedem os eventos cotidianos e míticos pode determinar a relacionalidade dos seres ou dos objetos, muitos dos quais definem eventos de predação em que os atores ocupam papéis intercambiáveis e opostos, segundo o ambiente circundante: a mesma forma material vital volitiva pode ser presa ou predador (Århem 1996b). Essa mobilidade do ator apreende e compreende o espaço ou o contexto imerso em ajustes e conciliações do ambiente (Ingold 2000:185), que se constitui por seus ocupantes em primeira instância. A predação é a ante-sala da finitude ou da infinitude do indivíduo.

Plantas, homens, cogumelos, animais, aracnídeos, pedras, montanhas, cursos de água e insetos parecem ter uma explicação fluida, que enfatiza a existência de uma estreita conexão entre todos os seres. Desse vínculo derivam-se transferências e transidentificações materiais, espirituais e essenciais entre as diferentes esferas da vida sensível (terrestre, aérea, aquática) e a estrutura material que as sustenta (montanhas, cursos de água, rochas). Longe de serem excepcionais, as conexões expressam-se na práxis e na conduta ecológica cotidiana dos indivíduos Jodï. Os argumentos dos mitos e das cosmologias Jodï sustentam-se em conhecimentos ecológicos, fenológicos e etiológicos extensos, com referentes concretos, sincréticos, utilitários, simbólicos, funcionais e cerimoniais definidores (por exemplo, as casas dos seres hipostáticos são montanhas ovais, assim como as casas humanas são funcionais e simbólicas; o curare foi criado pelo escorpião, sendo a metáfora homóloga da efetividade do veneno). 
No mito do sol, delineiam-se as pautas humanas definidoras, abundantes em relações com o espaço-tempo em que nasce e jaz a luz. A corporalidade humana atua como um eixo organizador central e como veículo de expressão individuada, girando ao redor de uma função social e cosmológica fundamental definida pela práxis da caça. Os Jodï existem para agirem cosmicamente como caçadores - e este nível estrutural é fundamental, embora não exclusivo, para a definição humana (Seeger et alii 1987:22). A ausência do movimento solar no tempo primordial desvela a própria essência da criação: o movimento/a mutação/a conversão. Além da aciclicidade de um espaço atemporal firmado pelo esquecimento da rota solar, o lugar inamovível do sol denota e conota um limbo estático que cancela qualquer possibilidade de transformação ou informação, ou seja, de vida. O caminho do sol Jodï é rota de vida e morte, princípio e fim de uma modalidade de ser, da mudança e da continuidade. jlïl jotï, os humanos reais, verdadeiros, vêm de onde ele sai e vão aonde se oculta o sol desde o início dos tempos, e sua existência é uma jornada entre ambos os extremos. O lugar onde surge o sol é fartamente habitado por seres essencialmente humanos e morfologicamente diversos (como jkonojto uli ja que, segundo algumas versões, moldou a primeira mulher); chegar lá é perigoso para os homens pois, no caminho, adquire-se ou perde-se a eternidade, perde-se ou ganha-se a possibilidade de ser só espírito.

Recebido em $1^{\circ}$ de julho de 2005

Aprovado em 9 de maio de 2006

Tradução de Sérgio Paulo Benevides

Egleé López é pesquisadora do Instituto Venezolano de Investigaciones Cientificas, Caracas, Venezuela. E-mail: <egleel@gmail.com>

\section{Notas}

*Agradeço aos Jodï por sua amizade, amabilidade e disposição em cooperar nos trabalhos de campo. Também por compartilharem seus lares e cuidados. Agradeço a Stanford Zent por suas palavras e assistência constante nos aspectos acadêmicos e nos cotidianos. Ajuda financeira e logística proveio do CONICET, da Wenner-Gren Foundation, do NSF e do IVIC. 
${ }^{1}$ Desde abril de 1996, Stanford Zent e a autora realizam pesquisas em diversas comunidades Jodï (nas áreas de ecologia humana, etnobotânica quantitativa, ecologia da conduta, etnomicologia, demarcação territorial etc.). Entre as variantes do etnônimo Jodï, encontramos os termos Chicano, Shikana, Orechicano, Waruwarú, Yabarana monteros, Jajá, Hotï, Hodï, Joti, Jodi, Jodï, Hoti, Yuana, Yowana, Rua e Rue. O sufixo dï indica plural de seres animados.

${ }^{2}$ Empregam-se aqui os conceitos clássicos de ecologia [oikos, lar, estudo do lar natural e das inter-relações entre seus componentes abióticos e bióticos], práxis [ação, prática, experiência] e poética [poiesis, criar, fabricar, construir, engendrar, dar à luz].

${ }^{3}$ Embora se tenham registrado algumas divergências nesse mito (seres, espécies envolvidas, adornos, instrumentos etc.) narrado por 55 Jodï (tanto em jodï quanto em espanhol), a síntese que ora se apresenta reproduz com fidelidade o tema central e a concatenação de eventos.

${ }^{4}$ Também se menciona como suporte muye jyeї (Copaifera officinalis L.).

${ }^{5}$ Também chamado jkëmabakä [o que é]. Outras versões mencionam seres equiva-

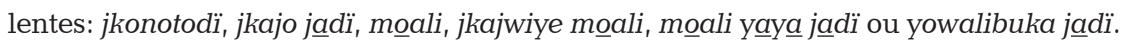

${ }^{6}$ Os Jodï usam muito poucos nomes próprios. ñamulie, primeira, au, mulher, é um apelativo não reconhecido como uma denominação pessoal. Ocorre o mesmo com ñamulie jaiñe e jkajo jạ. Nesses casos, percebe-se a diferença em relação a outras tradições ameríndias que dão importância aos nomes pessoais (Overing e Kaplan 1988:293; Alès 1998; Mansutti 2002).

${ }^{7}$ Conforme o pertencimento de grupo, outras espécies são reconhecidas como aquelas em que se talhou a primeira mulher alikwete lue jyeї (Inga bourgoni Aublet) ou jkiwi jyeï (Caraipa densifolia Martius), e assim se explica parcialmente a endogamia.

${ }^{8}$ Os Jodï hispanófonos traduzem o termo como alma. Entre os Desana, a alma assenta-se no coração (Reichel-Dolmatoff 1971:75). Para os Bororo (Crocker 1985:41), o sangue bombeado pelo coração impulsiona a alma. A força vital Eñepa situa-se no peito e nos lugares onde se sentem as pulsações sangüíneas (Henley 1988:283).

${ }^{9}$ A couvade é comum entre os grupos da Guayana venezuelana. Veja-se Butt Colson e Armellada 1983; Overing e Kaplan 1988.

${ }^{10}$ Por questões éticas, não se procede aqui à identificação de espécies que possam ter bioatividade e, portanto, interesse comercial.

${ }^{11}$ Segundo descrição de Henley (1988:281), o objetivo central da festa de iniciação masculina entre os Eñepa do norte é a perfuração do septo nasal. Nenhum informante Eñepa entrevistado pôde corroborar esse dado, embora a prática possa ter sido esquecida ou não ser freqüente entre os Eñepa do sul. 
${ }^{12}$ awela, termo polissêmico que define incontáveis seres, temidos predadores polimorfos, diferentes em sua temporalidade: hipostáticos, eternos ou finitos. Estes últimos são a transformação do mal, da moleza, da doença, da dor de quem morre, têm vontade própria, mas não sentido nem palavra (veja-se awetha Overing e Kaplan 1988; kanaimu Whitehead 2002 para outros grupos). Os hipostáticos são pessoas profusamente peludas, polimorfas, enormes, negras, altas, têm grande avidez por comer olhos. Os eternos ficaram presos no subsolo desde o último caos, vivem nas profundezas das montanhas e não podem sair de lá.

${ }^{13}$ A magia dos kanaimu dos Patamuna está associada a ervas e abóboras (Whitehead 2002); igualmente, a transformação de um homem em jkajo ja, segundo os Jodï, depende do uso apropriado de ervas e abóboras. As técnicas rituais associadas às vítimas humanas de kanaimà pretendem, como o iyu, desindividualizar, desumanizar a presa. Em ambos os casos, o fim último é a produção de comida para permitir a continuidade da vida. Hoje em dia, os Jodï negam a existência de jkajo ja por dois motivos: a desaparição das abóboras responsáveis pela transformação e pelo caos dos múltiplos assassinatos provocados pela superpopulação de jkajo jạdï na última destruição. É interessante notar que as plantas usadas pelos kanaimu são parte da parafernália cotidiana do caçador Jodï (em especial, Araceae, Marantaceae, Zingiberaceae etc.).

${ }^{14}$ Por exemplo, uli jkwayo tawï [árvore de macaco-aranha, Leonia sp.] unido ao uli jkwayo ae [protetor do macaco-aranha e predador] e ao uli jkwayo yakilo [cogumelo macaco-aranha, Lycoperdon sp.].

${ }^{15}$ Palmas, zarabatanas e muitos animais eram homens entediados na casa de jcho malidëkö (pessoa hipostática divina com hábito humano, cuja casa está onde nasce o sol), que caminham até a terra, dispersando-se e, por vontade própria, decidem especiar-se ao longo do caminho.

${ }^{16} \mathrm{O}$ mesmo princípio expressa-se na restrição à mistura de fluidos, como o sangue menstrual e o curare, combinação que debilita este e o caçador; bem como na tentativa de manter o sangue menstrual distante da preparação de comidas silvestres, pois o produto resultante pode tingir de negro o coração e levar à morte, caso os corpos não sejam lavados com fluidos vermelhos de águas paradas. Outros fluidos corporais são remédios exclusivos para danos corporais, como o sangue das grávidas, o leite materno, a placenta e o líquido amniótico das que deram à luz recentemente e são as únicas capazes de fazerem regressar a jnamo o corpo que fugiu envenenado.

${ }^{17}$ A importância do sangue como causador de doenças ou garantia de saúde e integridade (Foster 1953; Butt Colson e Armellada 1983) ou como componente essencial na fabricação dos corpos humanos (Alès 1998) é notável entre grupos ameríndios. 


\section{Referências bibliográficas}

ALÈS, Cathèrine. 1995. "Tierras sagradas y territorios amenazados. Los Yanomami más allá de su doble". In: A. Carrillo e M. Perera (orgs.), Amazonas: modernidad en tradición. Caracas: GTZ / CAIAH/Sada/Amazonas.pp.205-225.

. 1998. "Pourquoi les Yanowamï ont-ils des filles?". In: M. Godelier e M. Panoff (orgs.), La production du corps. Amsterdã: Editions des Archives Contemporaines/ Overseas Publishers Association. pp. 281-315.

ÅRHEM, Kaj. 1996a. "The cosmic food web: human-nature relatedness in the northwest Amazon". In: P. Descola e G. Pálsson (orgs.), Nature and society. Anthropological perspectives. Londres: Routledge. pp. 185-204.

.1996b. Makuna: an amazonian people. Sans Papers in Social Anthropology. Göteborg: Göteborg University.

BUTT COLSON, Audrey e ARMELLADA, Fray Cesareo de. 1983. "An amerindian derivation for latin american creole illnesses, and their treatment". Social Science and Medicine, 17(17):1229-1248.

. 1990. "El rol económico del chamán y su base conceptual entre los Kapones y Pemones septentrionales de las Guayanas". Montalban, 22:7-97.

CAYÓN, Luis. 2002. En las aguas de Yuruparí: cosmología y shamanismo makuna. Bogotá: Ediciones Uniandes.

CORMIER, Loretta. 2003. "Animism, canibalism and pet-keeping among the Guajá of eastern Amazonia". Tipiti, $1(1): 81-98$.

CROCKER, John. 1985. Vital souls: bororo cosmology, natural symbolism, and shamanism. Tucson: The University of Arizona Press.

DAMATTA, Roberto. 2000. "Individualidade e liminaridade: considerações sobre os ritos de passagem e a modernidade". Mana. Estudos de Antropologia Social, 6(1):7-29.

DE CIVRIEUX, Marc. 1980. Watunna: an orinoco creation cycle. San Francisco: North Point Press.

DEELY, John. 2001. Four ages of understanding: the first postmodern survey of philosophy from ancient times to the turn of the twenty-first century. Toronto: Toronto University Press.

DESCOLA, Philippe. 1996a. La selva culta: simbología praxis en la ecología de los Achuar. Quito: Abya-Yala.

. 1996b. "Constructing natures: symbolic ecology and social practice". In: P. Descola e G. Pálsson (orgs.), Nature and society: anthropological perspectives. Londres e Nova York: Routledge. pp. 82-103.

DELHI, John. 2001. "Umwelt". Semiotica, 134(1/4):125-135.

DIXON, Robert M. W. e AIKHENVALD, Alexandra. 1999. "Introduction". In: R. Dixon e A. Aikhenvald (orgs.), The amazonian languages. Cambridge: Cambridge University Press. pp. 1-22.

FOSTER, George. 1953. "Relationships between spanish and spanish-american folk medicine". Journal of American Folklore, 66:210-217.

HENLEY, Paul. 1988. "Los E'ñepa". In: J. Lizot (org.), Los aborígenes de Venezuela. Caracas: Fundación La Salle-Monte Ávila Editores. v. III. pp. 215-311.

HORNBORG, Alf. 1996. “Ecology as semiotics: outlines of a contextualist paradigm for human ecology". In: P. Descola e G. Pálsson (orgs.), Nature and society: anthropological perspectives. Londres e Nova York: Routledge. pp. 45-62.

INGOLD, Tim. 2000. The perception of the environment: essays on livelihood, dwelling and skill. Londres e Nova York: Routledge. 
JARA, Fabiola. 1996. El camino del Kumu: ecología y ritual entre los Akuriyó de Surinam. Quito: Biblioteca Abya-Yala.

LONDOÑO SULKIN, Carlos David. 2005. "Inhuman beings: morality and perspectivism among Muinane people (colombian Amazon)". Ethnos, 70(1):7-30.

LÓPEZ, Egleé. 2005. "The hunter-self: perforations, prescriptions and primordial beings among the Hodï, Venezuelan Guayana". Tipiti. No prelo. . e ZENT, Stanford. 2004. "Floristic composition of four forest plots: Sierra Maigualida, Venezuelan Guayana". Biodiversity and Conservation, 13:2453-2483.

MANSUTTI, Alexander. 1997. "Los gerentes de la selva". La Iglesia en Amazonas, 77:44-48.

. 2002. Le parcours des créatures de Wajari: socialisation du milieu naturel, système régional et migrations chez les Piaroa du Venezuela. Thèse de doctorat, EHESS, Paris.

OVERING, Joanna. 2003. "El yo consciente, la vida de los deseos y el apego a las costumbres: una teoría piaroa de la práctica". In: C. Alès e J. Chiappino (orgs.), Caminos cruzados. Paris e Mérida: IRD Éditions/ULA GRIAL. pp. 273-292.

. e KAPLAN, Myron R. 1988. "Los

Wóthuha (Piaroa)". In: J. Lizot (org.), Los aborígenes de Venezuela. Caracas: Fundación La Salle-Monte Ávila Editores. v.III. pp. 307-411.

PELUSO, Daniela. 2004. "'That which I dream is true': dream narratives in an amazonian community". Dreaming: Journal of the Association for the Study of Dreams. Special Issue: Anthropological Approaches to Dreaming, 14(2\&3):107-119.

REICHEL-DOLMATOFF, Gerardo. 1971. Amazonian cosmos: the sexual and religious symbolism of the Tukano indians. Chicago e Londres: The University of Chicago Press.
RIVAL, Laura. 1998. "Androgynous parents and guest children: the huaorani couvades". The Journal of the Royal Anthropological Institute (N.S.), 4(4):619-642.

ROOSEVELT, Anna. 1994 Amazonian indians from prehistory to the present: anthropological perspectives. Tucson: University of Arizona Press.

SEEGER, Anthony; DAMATTA, Roberto; VIVEIROS DE CASTRO, Eduardo. 1987 [1979]. "A construção da pessoa nas sociedades indígenas brasileiras". In: J. Pacheco de Oliveira Filho (org.) Sociedades indígenas e indigenismo no Brasil. Rio de Janeiro: UFRJ/ Editora Marco Zero. pp. 11-39.

SILVA MONTERREY, Nalúa. 1997. “La percepción ye'kwana del entorno natural". Scientia Guianae, 7:65-84.

STORRIE, Robert. 1999. Being human: personhood, cosmology and subsistence for the Hodï of Venezuelan Guiana. PhD Thesis, University of Manchester. . 2003. "Equivalence, personhood and relationality: processes of relatedness among the Hoti of Venezuelan Guiana". Journal of the Royal Anthropological Institute (N.S.), 9:407-428.

TAYLOR, Anne-Christine. 1993. "Remembering to forget: identity, mourning and memory among the Jivaro". Man, 28(4):653-678.

VILAÇA, Aparecida. 2002. "Making kin out of others in Amazonia". The Journal of the Royal Anthropological Institute (N.S.), 8:347-365.

VIVEIROS DE CASTRO, Eduardo. 1987 [1979]. "A fabricação do corpo na sociedade xinguana". In: J. P. de Oliveira Filho (org.), Sociedades indígenas e indigenismo no Brasil. Rio de Janeiro: UFRJ/ Editora Marco Zero. pp. 31-39. 1992. From the enemy's point of view: humanity and divinity in an amazonian society. Chicago: University of Chicago Press. 
1998. Cosmologies: multiculturalism and multinaturalism. General Lectures, Department of Social Anthropology, University of Cambridge. Ms. 2003. "Perspectivismo y multinaturalismo en la América indígena". In: A. Chaparro e C. Schumacher (orgs.), Racionalidad y discurso mítico. Colômbia: Centro Editorial Universidad del Rosario/ ICAH. pp. 191-243.

WHITEHEAD, Neil. 2002. Dark shamans, kanaima and the poetics of violent death. Dirham e Londres: Duke University Press.

WILBERT, Johanness. 1958. "Mitos de los Yabarana". Antropológica, 5:58-66.

WILBERT, Werner. 1992. "Bush-spirit encounters in Warao life and lore" Antropológica, 77:63-92. 


\section{Resumo}

Este trabalho consiste em uma etnografia sobre as noções de corporalidade e pessoa entre os Jodï, um grupo ameríndio ( 900 pessoas) da Serra Maigualida na Guayana venezuelana. Oferece-se, aqui, uma interpretação etnográfica sinótica de aspectos significativos dos discursos mitológicos e ritos hodï que permitem especular acerca da protologia e escatologia humanas, ilustradas em algumas práticas (predação, caça e espacialização do tempo). Este texto associa suas premissas teóricas ao perspectivismo, explorando três dinâmicas Jodï: 1) A espacialidade do tempo primordial e do atual; 2) O valor do som e seu contraponto com o silêncio e 3) A noção de alteridade consubstanciada com animais, artrópodos, plantas e fungos, a ponto de tornar difusos os limites discretos da pessoa. Pretende-se estabelecer linhas causais entre as idéias e práticas Jodï para comprender suas condutas ecológicas.

Palavras-chave: Jodï, Perspectivismo, Corporalidade, Pessoa, Indígenas amazônicos, Predação, Caça.

\section{Abstract}

The present work is an ethnography of notions of corporality and personhood among the Jodï, (a Native American group of around 900 people) in the Serra Maigualida in the Guyana region of Venezuelan. Here, we offer a synoptic ethnographic interpretation of the significant aspects of the mythological discourses and hodi rites which permit speculation regarding human protology and eschatology as illustrated by certain practices (predation, hunting and the spatialization of time). The theoretical premises utilized here, associated with perspectivism, explore three Jodï dynamics: 1) The spatial distribution of primordial and current time; 2) The value of sound and its counterpoint, silence; and 3) The notion of alterity as consubstantiated with animals, arthopods, plants and funguses to such a degree that the very borders of personhood become fuzzed. It is this article's objective to establish causal linkages between Jodi ideals and practices in order to better comprehend that people's ecological conduct.

Key words: Jodï, Perspectivism, Corporality, Personhood, Amazonian Indians, Predation, Hunting. 